\title{
A Note on Deregulation of Natural Gas Prices
}

THE PURPose of this paper is to bring to the attention of a larger, nonspecialized audience a possible change in policy that may have wide and costly ramifications: deregulation of natural gas prices. There is some value in making even rough "guesstimates" of the economic implications of price deregulation because of the general bias that both economists and businessmen have in favor of deregulation. ${ }^{1}$

It is easy to support that bias. Anyone who looks into gas price regulation even superficially will find a host of "horror stories" concerning resource allocation and seemingly arbitrary conferment of benefits. Gas prices at the wellhead vary from under $\$ 0.50$ per thousand cubic feet to over $\$ 8.00$. Distribution companies that have access to much lowprice gas can afford to pay great premiums for extra gas, which they then mix with the low-price gas and sell to the ultimate users (a practice known as rolled-in pricing).

Deregulation of gas prices would eventually eliminate these allocational and distributional distortions, at least after existing contracts have expired. But deregulation would have other consequences that, when taken altogether, might well be far worse than the distortions. The magnitude of these effects-redistribution from consumers to producers, macroeconomic impacts, and increased dependence on oil imports, each of which is discussed below in turn-depends greatly on the extent to which the existing price regulations have suppressed gas prices. It is widely assumed that gas competes directly with oil, especially residual

1. For a recent representative statement in favor of deregulation, see Committee for Economic Development, Energy Prices and Public Policy (Washington, D.C., July 1982). The project directors were Thomas C. Schelling and Grant Thompson. 
fuel oil in industrial uses and distillate fuel oil in residential and commercial space heating, and therefore that gas at the burner tip should and would, without the existing regulations, command a similar price on a heat-equivalent basis. Wellhead gas prices would then be determined after allowing for the costs of pipeline transportation and distribution to consumers. Because on average gas prices have been well below oil prices on a heat-equivalent basis, it is generally assumed that complete deregulation of gas prices would lead to a sharp jump in the average price of natural gas-on the order of 50 percent at the burner tip (somewhat less for residential use, more for industrial use), and even more at the wellhead.

For reasons that are discussed below, there is good reason to doubt that the equilibrium price of gas would jump by anything like these amounts upon complete gas price deregulation in 1982 or 1983, and it might not increase at all. However, under existing contractual arrangements actual gas prices would jump by a large amount-perhaps even more than 50 percent on average-upon immediate decontrol, not because of competition with oil but because of the requirements of existing contracts, leading to a substantial temporary movement of gas prices above their equilibrium price. In view of this likely increase, the analysis that follows proceeds on the assumption that gas deregulation would in fact lead to a sharp jump in gas prices.

Before turning to those issues, however, it will be useful to provide a brief history and some essential explanation concerning the regulation and use of natural gas in the United States.

\section{Background}

Gas price regulation by the federal government began with the Natural Gas Act of 1938; state regulation goes back even further. The 1938 act authorized the government to regulate the price of gas sold to local distributors and ultimate consumers by pipeline companies engaged in interstate commerce. Pipelines were considered a natural monopoly calling for such regulation. Within its domain a pipeline was often a monopoly seller of gas and a monopsonistic buyer of gas. Regulation of pipelines naturally led to regulation of the wellhead price of producing 
companies owned by pipeline companies, to prevent intracompany transfer pricing from thwarting the purposes of the Natural Gas Act. Then in 1954 the Supreme Court ruled that the Federal Power Commission's authority also extended to independent gas producers who sold to pipelines engaged in interstate commerce. Gas moving in intrastate commerce was left unregulated by federal authorities, although some states continued to regulate.

This situation prevailed until 1978. Between 1954 and its peak in 1973, natural gas production in the United States more than doubled. Production exceeded additions to proven reserves after 1967, and in the mid1970s gas shortages developed and curtailments of gas use were introduced to ration the limited supplies in interstate commerce, where gas prices were below those in the more lightly regulated intrastate commerce.

This regulatory regime was substantially altered with the Natural Gas Policy Act (NGPA) of 1978. This act extended federal jurisdiction to intrastate gas and divided gas into twenty-four different categories for regulatory purposes. Its ultimate objective was to reduce the discrepancy between gas prices and oil prices by introducing a phased and partial scheme for deregulation of gas prices. Certain unconventional sources of gas (gas from depths below 15,000 feet, from Devonian shale, from coal seams, and from geopressurized brines) were decontrolled as of November 1979. "New" gas-from wells developed after April 20, 1977-and gas dedicated to intrastate commerce before that date is to be decontrolled on January 1, 1985, or in mid-1987, depending on the exact status of the gas. Old gas dedicated to interstate commerce is to remain under control indefinitely, subject to a price escalation factor equal to the GNP deflator plus 0.2 percent a year. New gas is also subject to escalation while it remains under price control; typically the escalation is somewhat higher, running as high as the GNP deflator plus 4.2 percent a year. The president or Congress can reimpose price controls under NGPA for a period of up to eighteen months after decontrol has occurred.

This regime of phased and partial decontrol was conceived before the second major increase in oil prices (1979-80) and relied on the assumption that world oil prices would be about $\$ 15$ a barrel in 1985 . The escalation of price ceilings between 1978 and 1985-87 was keyed to this assumption. With much higher oil prices, execution of the NGPA holds the prospect of a sharp jump in gas prices during the mid-1980s. The Reagan admin- 
Table 1. Profile of U.S. Energy Consumption, 1981

Quads $^{\mathrm{a}}$

\begin{tabular}{|c|c|c|c|c|c|}
\hline \multirow[b]{2}{*}{$\begin{array}{c}\text { Primary } \\
\text { energy source }\end{array}$} & \multicolumn{4}{|c|}{ Sector } & \multirow[b]{2}{*}{ Total $^{\mathrm{b}}$} \\
\hline & $\begin{array}{l}\text { Residential and } \\
\text { commercial }\end{array}$ & Industrial & Transportation & $\begin{array}{l}\text { Electric } \\
\text { utilities }\end{array}$ & \\
\hline Coal & 0.2 & 3.1 & $\ldots$ & 12.7 & 16.0 \\
\hline Natural gas & 7.4 & 8.0 & 0.6 & 3.8 & 19.8 \\
\hline Petroleum & 3.1 & 8.1 & 18.5 & 2.2 & 32.0 \\
\hline Nuclear energy $^{c}$ & $\ldots$ & $\ldots$ & $\ldots$ & 2.9 & 2.9 \\
\hline \multicolumn{6}{|l|}{ Hydro and other } \\
\hline power & $\cdots$ & $\ldots$ & $\ldots$ & 3.1 & 3.1 \\
\hline Total primary & 10.7 & 19.2 & 19.2 & 24.6 & 73.8 \\
\hline Electricity ${ }^{d}$ & 15.0 & 9.6 & $\ldots$ & $(24.6)$ & \\
\hline $\begin{array}{r}\text { Total energy } \\
\text { consumed }\end{array}$ & 25.7 & 28.9 & 19.2 & $\ldots$ & 73.8 \\
\hline
\end{tabular}

Source: U.S. Department of Energy, Monthly Energy Review, May 1982, pp. 20-25.

a. One quad is equal to $10^{15} \mathrm{Btu}$.

b. Some components may not add to totals due to rounding.

c. Converted at the fossil fuel equivalent for thermal power generation.

d. Including losses in generation and transmission. Electricity sales were 7.2 quads.

istration argued in 1981 that for a variety of reasons immediate deregulation of gas prices was desirable. Congressional and public opposition prevented action then, but the issue remains a live one.

Before proceeding further, a word should be said about the relation between gas and other types of energy in the U.S. economy and about the different sources and categories of gas. Table 1 presents a profile of U.S. energy consumption in 1981, measured in quads. ${ }^{2}$ Natural gas accounted for about 27 percent of total energy consumption. Of total gas, 19 percent was used as boiler fuel for electric power and 40 percent by industry for all purposes, including boiler fuel, which competes with residual fuel oil and coal. This contrasts with gas use in Europe, where relatively little is used as boiler fuel.

2. Units of measurement are exceptionally confusing in the energy field. Americans usually measure natural gas in cubic feet, which when dry (so it is mostly methane) has a heat content of 1,026 British thermal units (Btu), plus or minus several Btu depending on the exact constituents of the gas. So a thousand cubic feet is about 1 million Btu. Elsewhere in the world the unit of measurement is the cubic meter, which equals 35.3 cubic feet.

The heat content of a barrel of crude oil also varies with its exact constituents, but averages about 5.8 million Btu, the equivalent of about 5,650 cubic feet of gas. A million billion Btu is called a quad, which is approximately the heat content of a trillion cubic feet of natural gas. 
There are several sources of gas. About one-fifth of the U.S. gas supply is produced in association with oil. The remainder of U.S. domestic production is nonassociated gas. Just over 4 percent of total supply is imported. Of this, most comes by pipeline from Canada and Mexico, but some gas is imported in liquified form (LNG), and small amounts of gas come from Alaska as LNG.

About two-thirds of U.S. domestic production in 1980 was "old" gas, not scheduled for deregulation under NGPA, and the remainder is to be deregulated in 1985-87. The share of this old gas will decline to less than one-half by 1985 as old wells are depleted and new ones come into production. If the Alaskan gas pipeline is completed on schedule, which now seems unlikely, about 0.76 trillion cubic feet of Alaskan gas will begin to flow into the lower forty-eight states by late 1986, and its price will be regulated.

\section{Economic Effects of Price Deregulation: Allocation}

The efficiency gains from deregulation are especially attractive to economists; it is their specialty. Deregulation will promote development of the sources of supply with lowest costs. In particular, drilling for highcost sources of gas, such as that below 15,000 feet for which there is incentive under NGPA, will presumably give way to less costly sources of supply. There will also be some rationalization of consumption, partly away from cheap gas, partly among users of gas, although how much misallocation exists is unclear. Some industrial users are now subject to "incremental" pricing, for instance, and have to pay more for their gas than do residential and commercial users. There are marked differences in price among various regions of the country, only partly explained by distribution costs, and these differences may influence the location of some industrial activity. Also, the unsatisfied demand for gas that is alleged to exist could be satisfied, although it is not clear how much actually exists. Some of these points are discussed further below.

The Department of Energy has attempted to estimate the "real resource costs" saved by immediate decontrol of energy prices. This estimate appears in the most comprehensive study that has been done to date on the effects of gas price deregulation, and I refer to it frequently below. The DOE's estimate of real resource savings from immediate gas 
price deregulation is small at first, but reaches $\$ 2$ to $\$ 3$ billion a year in 1980 dollars by the late 1980 s. $^{3}$

This estimate is described as "the area under the domestic gas supply curve," or, more accurately, the difference between that area under the reference regime, which is that prescribed in the NGPA, and that under immediate (January 1982) and complete decontrol at the wellhead. This savings is not a huge sum, but it is sufficiently large that it should not be ignored. It is worth noting, however, that most of the resources saved in this estimate simply result from lower gas production, not greater efficiency in the production of a given volume of gas. For instance, by 1990 the resources "saved" by immediate decontrol in comparison with decontrol under the NGPA come to $\$ 3.0$ billion in 1980 dollars; of this, $\$ 2.5$ billion is from a lower level of gas production, and only $\$ 0.5$ billion is from improvements in efficiency. On the other hand, perhaps the United States should not be producing so much gas, and the resources released can be better used elsewhere. This issue is taken up below. For the moment the allocational gains can be reckoned to be between $\$ 0.5$ billion and $\$ 3.0$ billion a year in 1980 dollars.

\section{Distributional Effects of Price Regulation}

In addition to allocational effects, there are distributional effects from decontrols. These have long been acknowledged by economists, but leave today's economists uneasy because they do not know how to evaluate them. In keeping with current practice, the effects will not be dealt with here, except to note two points. First, already developed natural gas probably comes as close as possible to a realistic example of a product with a pure rent. Once the well has been drilled and the gasgathering facilities installed, price increases represent a pure windfall. This point is acknowledged in the DOE Study cited above, which observes: "The change in the producer surplus . . . is likely to approximate the change in before-tax income because most of the change is from increased revenues from gas that would be produced under current

3. U.S. Department of Energy, Office of Policy, Planning and Analysis, A Study of Alternatives to the Natural Gas Policy Act of 1978 (DOE, November 1981), (hereafter referred to as DOE Study), Appendix C, "Macroeconomic Consequences of Natural Gas Decontrol,"' DOE/PE-0035, p. 9. 
policies." ${ }_{4}$ To be sure, there is some margin for further development of existing fields, and surface equipment must be maintained and occasionally replaced to keep wells operating. The NGPA allows for the costs associated with such maintenance and extension. But the potential for further development of existing fields is limited compared with opportunities for new gas exploration and development. In an economy sensitive to supply-side considerations, a tax on old gas (price controls being a "tax" whose "revenues" are passed directly to consumers) probably comes as close as possible to a tax with minimal undesirable incentives, at least on the production side.

Second, if, as is generally assumed, gas prices rise sharply following decontrol, the redistribution from consumers to producers will be strikingly large. The DOE Study estimated that price decontrol in early 1982 would have raised the average wellhead price from $\$ 2.09$ per thousand cubic feet in 1981 to $\$ 4.19$ in 1982 (in 1980 dollars, deflated by an estimate of the GNP deflator). ${ }^{5}$ This price increase, passed on to consumers with no further escalation by distributors, would transfer about $\$ 38$ billion (1980 dollars) a year from gas consumers to gas producers on the volume of gas assumed to be consumed following decontrol. Under the NGPA average gas prices would have risen only $\$ 0.18$ per thousand cubic feet from 1981 to 1982 , so over 90 percent of the transfer can be attributed to decontrol. A substantial but indeterminant amount of the transfer to producers $-\$ 11$ billion (in 1980 dollars) in one estimate-would be recouped in income, royalty, and severance taxes; but even after allowing for that, an astounding transfer would take place in a single year. ${ }^{6}$

4. DOE Study, Appendix D, "Distributional Consequences of Natural Gas Decontrol," DOE/PE-0036, p. 41.

5. DOE Study, Appendix A, “Two Market Analysis of Natural Gas Decontrol,"'DOE/ PE-0033, summary report tables, REFFUL 82.

6. The $\$ 11$ billion estimate is from Dale Jorgenson Associates. It appears in the DOE Study, Appendix C, "Macroeconomic Consequences," pp. I-12, I-13. The American Gas Association, a trade organization of gas distributors which, in contrast to the DOE, opposes immediate gas price decontrol, finds an especially strong impact of the price increases on low-income households. It suggests that the share of income spent on gas in households with annual income below $\$ 7,000$ in 1981 would rise from 11 percent to 19 percent following decontrol. Its simulation study shows a larger price increase than does the DOE Study, and a total increase in expenditures by gas users of $\$ 60$ billion. See the AGA, "Cost of Immediate Total Wellhead Price Decontrol of Natural Gas to Low Income and Disadvantaged Groups," in Natural Gas Supply Outlook, Hearings before the Subcommittee on 
To determine if a change in policy will improve potential social welfare, economists ask whether those who gain from the change can compensate the losers and still come out ahead. If the distributional effects of gas price decontrol are this large, and if the allocational gains reported earlier are anywhere near correct, it would take an extraordinary effort for the gainers to compensate the losers. Producers would be left with less, perhaps much less, than 10 percent of the total transfer. It must be asked whether such retransfers, if they were to take place, could be made without affecting overall allocational efficiency even more than the gas price regulations do.

\section{Macroeconomic Effects}

If gas prices increase so much that they create such large distributional effects, there is bound also to be a major macroeconomic impact. The long-run effect on total output will be positive to the extent that the $\$ 0.5$ billion to $\$ 3.0$ billion allocational savings can be effectively utilized. But the short-run effect will be negative. The large redistribution will surely reduce aggregate demand in the short run as gas consumers cut their nongas spending (so they can pay higher gas bills) faster than the highincome producers increase their expenditures on goods and services, or others increase their spending after borrowing in the capital market. The redistribution will have an effect similar to that of the large increase in world oil prices in 1974-75 and again in 1979-80. Some of the gains to producers will be paid as taxes- $\$ 11$ billion was the figure cited aboveso there will also be a negative fiscal effect on aggregate demand, which may be welcome, depending on the overall condition of the economy.

In addition, the gas price increase will raise the general level of prices. (Gas constitutes over 1 percent of the consumer price index and 2.1 percent of the producer price index.) Since other prices in the economy will not automatically be cut to offset the rise in gas prices, the price

Fossil and Synthetic Fuels of the Committee on Energy and Commerce, House of Representatives, 97 Cong. 1 sess. (Government Printing Office, 1982), serial 97-90, p. 148. Only about one-third of gas consumption is by residences; the remainder would result in transfers within the business sector. 
index must be stabilized through the medium of weaker aggregate demand. If the Federal Reserve holds to its present monetary targets, a gas-induced rise in the price level will lead to a decline in economic activity.

The DOE Study already referred to reports three different simulations of the macroeconomic effects of gas price deregulation, summarized in table 2. Compared with policy under the NGPA, they all show increases in the price level and a decline in real GNP during the three years following deregulation, ranging from $\$ 21$ billion to $\$ 40$ billion in 1980 dollars. The Jorgenson model differs conceptually from the other two in that it focuses exclusively on supply-side effects: "desired expenditure (demand) is always consistent with what is achievable from production." ${ }^{7}$ Monetary aggregates are implicitly accommodative, but there is no wage-price interaction. The Wharton model and that of Data Resources Incorporated, in contrast, both allow for shortfalls of aggregate demand, and both include some influence of prices on wages. The Wharton model, however, assumes quite an accommodative monetary policy (M2 is 2.6 percent higher three years after decontrol than in the reference case); this is reflected in the larger cumulative price increase and the smaller cumulative reduction in output than that shown in the DRI simulations, which assume a steady increase in unborrowed bank reserves regardless of the rise in prices.

If the Federal Reserve aims to keep nominal GNP on a steady path, a target that has been frequently proposed in recent years, and if it succeeds in attaining this target continuously - an admittedly severe stipulationthe loss in output from gas price deregulation could be much higher. A rough idea of this magnitude can be garnered by supposing that monetary policy actions are sufficiently restrictive to ensure that nominal GNP after gas price decontrol follows the same path that it would in the absence of decontrol. Using the Wharton simulation reported by the DOE to characterize the latter situation, and assuming that only half of the resulting monetary squeeze affects real output (the other half lowering the general price level), the loss of output following decontrol for the first year would be $\$ 26$ billion in 1980 dollars, and the three-year loss would be $\$ 100$ billion. These losses are much higher than the figures

7. DOE Study, Appendix C, "Macroeconomic Consequences," p. I-15. 
Table 2. Estimates of Macroeconomic Effects of Gas Price Decontrol ${ }^{\mathrm{a}}$

\begin{tabular}{lcclcc}
\hline \multirow{2}{*}{ Model } & \multicolumn{2}{c}{$\begin{array}{c}\text { Effect on real GNP } \\
\text { (billions of 1980 dollars) }\end{array}$} & & \multicolumn{2}{c}{$\begin{array}{c}\text { Effect on GNP deflator } \\
\text { (percent) }\end{array}$} \\
\cline { 2 - 3 } \cline { 5 - 6 } \cline { 5 - 6 } & First year & First three years & & First year & First three years \\
\hline $\begin{array}{l}\text { Jorgenson } \\
\text { Wharton }\end{array}$ & -8.5 & -20.9 & & 2.2 & 1.6 \\
$\quad \begin{array}{c}\text { Econometrics } \\
\text { Data Resources } \\
\text { Incorporated }\end{array}$ & -11.8 & -27.9 & & 2.5 & 3.1 \\
\hline
\end{tabular}

Source: Department of Energy, Office of Policy, Planning and Analysis, A Study of Alternatives to the Natural Gas Policy Act of 1978 (DOE, November 1981), Appendix C, "Macroeconomic Consequences of Natural Gas Decontrol," DOE/PE-0035, pp. I-16, II-7, III-8, III-11.

a. Results are differences between simulations based on the Natural Gas Policy Act of 1978 and simulations that assume immediate decontrol in early 1982.

given in table 2, and they illustrate starkly the losses in output that can occur from "exogenous" price increases in an environment in which monetary policy successfully targets nominal GNP.

These short-run depressive effects could dominate the allocational effects even in the long run. Output lost forever means lost investment, which lowers total output and labor productivity in the future. The United States will experience for many years the enormous costs of the Iranian revolution and the Federal Reserve's reaction to it. In the DRI simulation, investment is reduced during the first three years by the equivalent of 5 percent of one year's investment.

\section{Oil Imports}

Besides allocational, distributional, and macroeconomic effects, policy should also be concerned with the impact of gas-price decontrol on oil imports, hence on U.S. dependence on oil from the rest of the world. The costly impact of two major world oil price increases in the past decade has already been mentioned. Four other major disruptions to Middle Eastern oil have occurred since 1950, although Americans are less aware of them because they were better able to cope with them. Very likely there will be at least one major disruption in the next decade, perhaps more, and the United States should position itself so that the damage will be limited. That entails many actions (such as building up the Strategic Petroleum Reserve), but among them is reducing U.S. 
dependence on imported oil. William Nordhaus calculated the gains that would flow from reduced imports of oil, taking into account the terms of trade effects and the costs of disruption, and suggested that the social value of a barrel of imported oil is roughly twice its price ${ }^{8}$ Regardless of the exact estimate, savings from reduced oil imports during periods in which the market is firm has social value substantially in excess of its price because of the improvement in the terms of trade such savings would permit and, more importantly, because of the macroeconomic costs that would be avoided if a disruption in foreign oil supplies should occur.

What effect will gas price decontrol have on imported oil? At first blush, it might seem that raising gas prices would induce substitution of oil for gas, or at least slow down the substitution of gas for oil that has been taking place. ${ }^{9}$ Once again, the DOE Study addresses the question in detail, estimating the impact on gas consumption, gas supply, and substitution for oil under a variety of assumptions regarding both the nature of the change in policy and the external economic environment. In view of developments during the past two years, the DOE's low oilprice scenario seems the most realistic of those the study examined. This assumes a fall in crude oil prices in 1980 dollars to $\$ 29.60$ a barrel in 1982 , followed by a 2 percent a year increase in real terms at least until 1995 , when the study's simulations end. ${ }^{10}$ The DOE assumes that this price path is exogenous and that gas prices will rise under decontrol to those of the Btu equivalent of residual fuel oil, with which gas competes at the margin. Under these assumptions, the DOE finds a drop in oil imports for the three years after full decontrol, relative to what would take place under the NGPA, followed by a gradual rise in oil imports in subsequent years. For the entire 1982-95 period, oil imports would be about 700,000 barrels per day higher with immediate full decontrol. This

8. William D. Nordhaus, "Oil and Economic Performance in Industrial Countries," BPEA, 2:1980, p. 387.

9. Between 1978 and 1981 the electric utilities sector reduced its consumption of oil by 1.6 quads ( 7 percent of its total primary energy consumption), increased consumption of gas by 0.5 quad, and increased consumption of coal by 2.5 quads. In the same period industrial users reduced their consumption of oil by 1.9 quads, gas by 0.6 quad, and coal by 0.2 quad, for a total decline of 9 percent in their energy use. Data are from DOE, Monthly Energy Review, May 1982, pp. 23, 25.

10. The average OPEC crude oil price in June 1982 was slightly lower $-\$ 28.96$ a barrel in 1980 dollars. 
is not a very great effect. But it has an undesirable time profile, with oil savings during the present period of world oil surplus, followed by increased oil imports in the 1985-95 decade, during which time an oil crisis is more likely to occur. The macroeconomic effects would amplify this pattern, depressing oil imports even further in the early years but raising them in the later years.

This pattern of impact on oil imports is determined by several key assumptions: (1) before decontrol there is an unsatisfied demand for gas by electric utilities and industry, such that increased availability of gas following decontrol will stimulate substitution of gas for oil despite a rise in the price of gas relative to the exogenous price of oil; (2) higher gas prices will discourage consumption in the residential and commercial sectors, which will result in lower total energy consumption rather than a substitution of oil for gas; and (3) decontrol of gas prices will lead to additional domestic gas production in the years immediately following decontrol, though not over a longer period of time.

All three assumptions need to be questioned, especially the first and the third. The DOE assumes a substantial unsatisfied demand for gas in 1981 (3.5 trillion cubic feet, or about 3.6 quads). The origin of this estimate is entirely unclear; it seems to derive from a demand-for-gas schedule based on the a priori assumption that gas competes at the margin directly with residual fuel oil at electric utilities and for industrial users. This assumption is crucial to the otherwise paradoxical result that a sharp relative increase in gas prices will stimulate demand for gas. It is true that under the Powerplant and Industrial Fuel Use Act of 1978 some industrial uses of gas were prohibited. But waivers of these prohibitions were granted generously, and restrictions on gas use by existing plants were abolished in 1981 (although building new gas-fired thermal electricity generating plants is still prohibited). Some areas of the country, notably New England and Florida, seem constrained in their gas consumption by limited pipeline capacity. That can be relaxed in the long run but will not occur at once following decontrol and is not dependent on decontrol. Apart from this, the supply of gas seems not to be a constraint on its consumption, now or in 1981; widespread testimony avers that U.S. gas production is limited by the lack of demand, not the reverse. ${ }^{11}$

11. See, for example, Natural Gas Supply Outlook. 
Why is it that firms do not switch from oil to gas when the latter is cheaper? Gas at the burner tip has been cheaper than the competing oil products for the past three decades, not only since the sharp oil price rise of 1974. The reason partly no doubt rests on the greater flexibility of oil, both in volume and in sources of supply. Memories of the gas supply curtailments of 1976-77 inhibit heavier dependence on gas. Perhaps some potential users hesitate because of the prospects of higher gas prices with decontrol, based on their belief that the anticipated savings would not warrant the investment. Perhaps it is also because they know, DOE statements notwithstanding, that deregulation does not assure uninterrupted future supply. Shortages can and do develop in markets not subject to regulation; and in any case government policy could change again and reintroduce physical curtailment-indeed it is likely to do so if serious shortages were to develop. ${ }^{12}$

Two further problems arise with this DOE assumption. First, the price of oil is not exogenous. If deregulation indeed would lead to a drop in demand for residual fuel oil (resid) as a result of increased gas for boiler fuel, the flexible prices of resid would fall, thereby inhibiting the substitution of gas for oil in the short run. In the long run, resid can be upgraded to lighter products if its price is expected to be low enough to warrant the heavy investment required. But given the shift in world oil production toward heavier crude oils, a relatively abundant supply of resid is likely for some time.

Second, coal is cheaper than gas even at its current prices, and much more so at oil-equivalent prices. If investments are to be made in the long run on the basis of Btu costs, coal dominates gas. Obviously there will be both environmental and locational obstacles to the universal use of coal as a boiler fuel during the next ten to fifteen years. Delivered coal will be more expensive than gas in a few areas, and antipollution investments increase the costs of using coal. But coal is still generally cheaper than gas for base-load facilities (that is, the main generation of

12. It is simply an evasion to claim that "shortages" cannot develop in a free market because price will rise to the point at which the market is cleared. Would-be buyers of sugar in 1974 will remember the difficulties they had in finding it, despite a free market. Furthermore, for the persons driven out of the market by high prices, especially if the expenditure is initially a consequential fraction of their income, there is effectively a shortage. And they will act politically on that perception. 
electricity, to which more flexible supplemental peak-load capacity may be added), and the switch to coal is likely to continue.

In short, there is not likely to be much substitution of gas for oil in utility or large industrial boiler use either in the short or the long run. Gas distributors apparently share this perception, for they have opposed deregulation of gas prices partly on the grounds that demand for gas would fall, not rise.

The second important assumption in the DOE analysis is that higher gas prices will discourage residential and commercial consumption of gas without inducing a rise in the demand for oil. That is, these users will simply cut their energy consumption when gas prices rise. The estimated drop in consumption is 540 billion cubic feet, or about 7 percent, in response to an initial price increase to them of 36 percent. It is probably correct that this group of users would not substitute oil fully for their reduced gas consumption, but it seems implausible that they would make no substitution at all. In particular, the pace of residential conversion to gas, with new investments needed by households, is likely to be slowed by a sharp increase in gas prices. Thus oil imports will be larger than they otherwise would be. ${ }^{13}$

The third key assumption is that gas price deregulation will stimulate new supplies of gas, by an estimated 200 to 400 billion cubic feet a year in the three years following decontrol. It is this increased supply, along with reductions in residential and commercial demand, that permits industrial consumers and utilities to use more gas and thereby to reduce the demand for imported oil. It can be taken for granted that higher wellhead prices will stimulate exploration and development of new sources of gas. Average wellhead prices of gas have risen sharply in the past decade, from $\$ 0.22$ per thousand cubic feet in 1973 to $\$ 0.90$ in 1978

13. From the point of view of social welfare, it is unclear that a switch in gas use from households to industrial boilers-which is what happens in the DOE simulations-is an allocational improvement. Gas prices for residences are considerably higher than for electric power companies ( $\$ 4.56$ versus $\$ 2.92$ per thousand cubic feet in 1981 ), presumably reflecting the higher costs of distribution to households. But from a social point of view, in the current context most of those distribution costs are already sunk, whereas new investment would be required for industrial hookups. If the gap between burner-tip price and relevant marginal social cost is higher for gas sales to households than that for sales to industrial users, which may well be the case because of sunken fixed costs of distribution, a switch in gas supplies from households to utilities and some other industrial users would result in a less efficient, not a more efficient, use of gas resources. 
to $\$ 2.06$ in 1981 , and this has no doubt helped to explain the sharp rise in new exploratory and developmental drilling since the early 1970 s.

But it is necessary to keep in mind the complexities of the NGPA governing gas price regulation. Some prices have already been decontrolled, and others have been allowed to rise sharply, precisely with a view to stimulating new supplies. These high prices are rolled in with the low-priced old gas for sale to users. With price deregulation, some of these wellhead prices will certainly fall, and to that extent will discourage new production, not encourage it. Yet raising sharply the prices of old gas may fail to stimulate new production. Thus deregulation of gas prices will not necessarily evoke more supply; it could even reduce the rate of the past few years at which new proven reserves have been found.

The DOE Study projects a marked decline in U.S. gas production until prices are deregulated under the NGPA. This is inconsistent with the essentially steady gas production that has been observed during the past three years under gas price regulation and with the increase in proven reserves that has recently occurred. Moreover, other observers project much less decline in production in the early 1980s under the NGPA than does the DOE. ${ }^{14}$ In view of recent production and exploration, the supply estimates in the DOE Study under continued price regulation have a sizable downward bias, which in turn imparts an upward bias to its estimates of oil savings in the years immediately following deregulation. If there is a decline in production and a weakening of exploration, it is more likely to be because of limited demand than because of inadequate price incentives relative to production or exploration costs.

The net effect of these judgments is to reduce substantially the oil savings that the DOE Study projects in the early years following gas price decontrol, and thus to enlarge the estimate of the increase in oil import dependence that gas price decontrol will bring about over the

14. See DOE Study, Appendix C, "Macroeconomic Consequences," p. III-53, in which Wharton Econometric's estimate of U.S. gas production in 1984 under the Natural Gas Policy Act is over 10 percent higher than the DOE's estimate, even though wellhead prices are assumed to be somewhat lower (p. III-36). Recently the DOE revised its own estimate for 1985 upward by 1.1 trillion cubic feet, or about 6 percent. See Department of Energy, Office of Policy, Planning, and Analysis, Energy Projections to the Year 2000, July 1982 Update (DOE, August 1982), pp. 5-11. 
entire period until 1995. Whatever efficiency gains may be brought about by decontrol could be overwhelmed by the cost associated with enlarged dependence on imported oil after 1985.

In this regard, gas price deregulation is very different from the oilprice decontrol that occurred in 1979-81. Although oil-price decontrol also could be expected to have some allocative, redistributive, and macroeconomic effects, it clearly served to reduce markedly U.S. dependence on imported oil, an important objective. Decontrol did this both by stimulating domestic oil supply and by discouraging demand for oil. Immediate gas price deregulation would be a move in the wrong direction on this dimension of national policy.

\section{Concluding Observations: Misplaced Analysis?}

If the above analysis of production and substitution is valid, it raises the interesting possibility that deregulation would increase the average equilibrium price of gas by much less than is generally assumed. Demand for gas could be satisfied by existing and prospective supply at close to existing average prices. ${ }^{15}$ Only if producers actually reduced their production, perhaps in anticipation of higher prices in the more distant future, would the price increase sharply. And, as noted, incentives to develop new sources of gas in the near future would be reduced.

There would of course be a major redistribution of earnings among producers, with producers of old gas earning much more, but with currently decontrolled and possibly even new gas producers receiving less. In short, perhaps the widespread assumption that gas prices would

15. Indeed, one line of argument suggests that the average equilibrium wellhead price of gas should not rise at all following price decontrol. Gas extracted from great depths is at present decontrolled. Therefore prices of deep gas should have risen, on Le Chatelier's principle concerning the equalization of pressures, to the point at which the average rolledin gas price would clear the market. Following total decontrol, below-average prices would rise, but they would be exactly compensated by a fall in above-average prices, leaving the average price unchanged.

In reality, the full operation of this equalization principle is thwarted by the still small and uncertain quantities of decontrolled gas, combined with an unwillingness of pipeline companies to make commitments over the lifetimes of contracts to prices well above present Btu-equivalent oil prices. It is also thwarted by the unavailability of such gas in the producing areas of some pipeline companies. Nonetheless, the tendency toward equalization is present, and this will sharply limit the rise in average equilibrium gas prices. 
rise sharply to Btu equivalence with current oil prices is incorrect. If so, there would be much more modest redistribution from consumers to producers, and the inflationary and contractionary effects of price deregulation would also be more modest, perhaps even negligible.

This happy possibility is made unlikely by several features of existing gas contracts, which give rise to the "fly-up" problem-a sharp initial rise of prices, following deregulation, above the long-run equilibrium price. Many existing contracts between gas producers and pipeline companies are on a "take or pay" basis, whereby pipeline companies are committed to pay for a large fraction of the contracted gas volumes whether or not they take it. Contracts between pipeline companies and local distributors, in turn, set a rather high minimum payment, whether the gas is taken or not. In addition, many contracts have a most-favoredtreatment clause and some have indefinite escalator clauses linked to 100 or even 110 percent of distillate fuel oil prices. ${ }^{16}$ Prices today are thus restrained well below what these contract escalators would call for in the absence of regulation. With price decontrol, the price escalators would be triggered, and this combined with the most-favored-treatment clauses would lead to a sharp jump in wellhead prices to most pipeline companies. Because of the take-or-pay clauses, the gas producers would be partially insulated from price-induced weakness in final demand for gas and could simply conserve any gas not taken. Given U.S. business habits and uncertainty about the short-run demand schedule, pipeline companies would pass on these price increases to distributors, and distributors would in the first instance pass them on to gas consumers (which they can typically do under the fuel price adjustment provisions of current local public utility regulations). Thus with deregulation a sharp increase in average prices would be experienced, even in the presence of a responsive decline in final demand. Deregulation would in effect unintentionally exert the collective short-run monopoly power of

16. According to a study of the 20,000 gas-purchase contracts on file with the Federal Energy Regulatory Commission, successor to the Federal Power Commission, about twothirds had indefinite escalator clauses. Of those, 8 percent had price escalators linked to distillate fuel prices and 83 percent had most-favored-treatment clauses linking prices to the one to three highest contract prices for the same area. See Congressional Research Service and National Regulatory Research Institute, Natural Gas Regulation Study, prepared for the Subcommittee on Fossil and Synthetic Fuels of the House of Representatives, Committee on Energy and Commerce, 97 Cong. 2d sess. (GPO, 1982), p. 144. 
the nation's gas producers. Prices would subsequently decline only as rapidly as the contracts expired or as they could be renegotiated to take into account the actual demand for gas.

If gas consumption declined markedly in response to the price increases, distributors would feel the financial squeeze. Under prevailing institutional arrangements, this squeeze could go on for several years before resulting in a decline in gas prices toward their equilibrium level. To reduce their financial straits, distributors will appeal to local public utility regulators to permit price discrimination among their customers, and in particular to lower their prices to industrial users with a high elasticity of demand for gas, arguing, with some justification, that such action will also permit lower prices to other customers.

Under these circumstances, for several years gas price deregulation would lead to the worst possible combination of outcomes: major redistribution from consumers to producers, inflation, economic contraction leading to unemployment, an increase in oil imports, and a misallocation of resources-in this case a movement from gas to other energy sources as well as a reallocation among gas users. 


\section{Comments and Discussion}

W. David Montgomery: This is both a good and a treacherous time to discuss the pros and cons of natural gas regulation. These two observations stem from the same fact: natural gas markets are in turmoil and are drastically different from what was forecast as little as one year ago. The turmoil has focused attention on problems of natural gas regulation, but the unanticipated changes in gas markets have made past studies of deregulation obsolete.

Richard Cooper has raised a number of uncertainties and important questions about the consequences of deregulation. It is certainly appropriate to take a new look at deregulation, based on current gas market conditions and trends. But in doing so I come out with conclusions that are exactly opposite those in the paper.

To state my disagreement briefly, I make three general observations and then state without proof a few conclusions. The first observation is that natural gas markets have changed. Oil prices have turned out to be much lower than the forecasts that were included in most recent studies and critiques of the Natural Gas Policy Act. Gas prices are much higher on average, because of various ways in which producers have adapted to the NGPA's price categories and managed to move gas from low to high price categories without doing anything to produce more gas. Gas demand is also lower than what was forecast, and large regional differentials in the cost of gas have appeared.

The second observation: to analyze equilibrium in the gas market, one has to start at the burner tip and look at the uses of gas and competition with alternative fuels. The price of gas at the burner tip is likely to be determined by competition with some form of fuel oil. The average price at the wellhead will equal the burner tip price net of 
transportation costs, and will therefore be insensitive to differences between partial and complete deregulation-unless supply response is so large as to shift burner tip equilibrium away from the point at which the marginal user is one whose alternative fuel is residual fuel oil.

The third observation is that it is necessary in discussing natural gas deregulation to pay careful attention to which alternative scheme of deregulation is being compared to which. Perhaps, having followed this subject for some time, I am particularly sensitive to the esoteric distinctions that the principals in this debate always make.

Current law, NGPA, occupies an intermediate position of partial deregulation. As Cooper mentioned, some gas is currently decontrolled. In 1985 approximately 50 percent of gas will become free from controls under present law. That is effective deregulation in the sense that the market would be cleared by prices under the NGPA schedule.

The alternatives to partial deregulation that one might want to discuss are, on one hand, continued controls-rolling back or freezing the current ceilings, and on the other, total deregulation-removing controls from old gas as well as new. The year in which one makes these comparisons also matters, because alternatives that differ drastically in one year may be indistinguishable in another. For example, Cooper compares total deregulation in 1982 to continued NGPA regulations in 1982, noting massive distributional consequences. But the cited DOE Study also predicted that NGPA would have similarly massive consequences in 1985, compared to continued controls.

I draw the following conclusions from the current state of the gas market and the changes that have occurred in other energy markets.

First of all, average gas prices have already risen and oil prices have fallen so much that to a first approximation, we could go from the current NGPA set of partial controls to complete deregulation of gas without any significant effect on the price that consumers see on average.

Nevertheless, complete deregulation would have substantial distributional and allocative effects. Some consumers would see considerably higher prices than they are paying now and others would see considerably lower prices. The consequences of unifying the price through complete deregulation would be an unambiguous efficiency gain. There are clearly unexploited gains from trade when one region pays $\$ 3$ per thousand cubic feet to heat houses and another pays $\$ 6$ per thousand cubic feet, and the difference has nothing to do with cost of transportation or 
production conditions. And there would be large transfers and redistribution among consumers. The same can be said about production. There are allocative inefficiencies in production because NGPA subsidizes the production of very high-cost gas. Equalizing wellhead prices would provide a more efficient supply of gas and would redistribute income among producers.

However, little of the redistribution that would take place under current market conditions would be between producers and consumers. This also means that this is a time when total deregulation would produce almost no inflationary or macroeconomic consequences from the demand-side effects.

All of the above concerns market equilibrium conditions. The contracts problem that Cooper describes is real, but it is a problem under current law as well as with total deregulation. Contracts will cause a large price spike in 1985 even if there is only partial deregulation in that year, and may already be forcing excessively high gas prices. It is not at all clear that total deregulation makes the problem worse. I suspect that by unifying prices, total deregulation would help.

I also do not feel that putting off deregulation is a way of solving this contracts problem. It reduces the incentive to reach voluntary agreements and leaves substantial market distortions in place. There are two more direct ways to address the contracts problem.

One is renegotiation; and my conversations with participants in the industry indicate that no one feels they are served well by existing contracts. Producers, pipelines, and distributors all see that if onerous contract provisions are enforced, they will be worse off than if they negotiate out a price at which the gas could be marketed by pipelines.

I think the solution is either to let the market take care of those contracts problems, or try a relatively simple legislative fix. Simply legislating a one-time market out of which everyone can renegotiate a contract that would otherwise have a price that spikes above the market equilibrium level would probably deal with the situation without perpetuating the inefficiencies of continued regulation.

I would like to point out possible implications for oil imports of the current large regional price differentials. In some regions consumers are being driven off gas, especially industrial and utility customers, because its price has gone above the cost of competing fuels. In these regions oil imports are increased. In other regions the price is so far below the oil 
parity level that bringing it up to the national average probably would not affect fuel choice decisions very much.

This asymmetry-which comes out of the fact that there is no single national price for gas-can reconcile the propositions that deregulation may for a time produce a higher average price for gas and higher gas consumption. But in the long run it is clear, and is stated in the DOE Study cited, that total deregulation gives higher price and lower consumption than will the NGPA. As supply depends increasingly on new discoveries and development, the market-clearing price will rise.

How should we evaluate a change in oil imports? I would argue that as a matter of public policy it is a bad idea to use a regulatory scheme to subsidize additional production of gas. The problems of the NGPA would be magnified if there were another sudden increase in the price of oil. The gas industry would remain hamstrung by price regulations that prevent drawing on its ability to produce and distribute substitute fuels for imported oil.

As a means of enhancing energy security, reducing oil imports is less important than building a system that is more flexible in responding to price changes. Total deregulation of natural gas would provide that increase in flexibility.

\section{General Discussion}

Robert Hall was critical of the DOE Study's conclusion that immediate gas decontrol would raise oil imports, reasoning that, if there is presently a gas shortage, price decontrol will raise prices and stimulate additional gas output, in which case oil imports would be expected to decline. And if there is no shortage, decontrol will affect neither prices nor imports. In fact, Hall believed that even if there is a shortage in areas that are controlled, it is doubtful that any aggregate shortage exists. Consequently the macroeconomic impact that would come from decontrol may be small and is quite different from that which resulted from the rise in the world oil prices. With respect to contract gas prices that are far above the equilibrium price, Hall pointed out that current commercial law permits the buyer to breach such contracts, with the buyer compensating the seller for this breach. In the context of long-term contracts, any price surprise from decontrol would confer rents on either buyer or seller. And if there were any large discrepancy between the contract 
price and the market-clearing price, buyer and seller would renegotiate. Therefore there cannot be any important discrepancy between the allocative price that governs consumption and the efficient, marketclearing price. Christopher Sims noted that the idea that contract renegotiations would be allocatively efficient depends on the assumption that both buyer and seller are in competitive markets. For example, if gas pipelines have substantial market power they might decide to pass through the inefficiently high price to final consumers, causing a misallocation of resources.

William Nordhaus questioned several points in Hall's analysis. He reasoned that whether gas production would rise with decontrol would depend on technical characteristics of gas production and the way prices are set. If regulators set a relatively low price on wells in which production is relatively inelastic but set high prices on wells in which production is elastic, it is very possible that production would decline under decontrol. Furthermore, as Cooper observes in his paper, if there is currently excess demand for gas, then whether imports will rise or fall under decontrol depends on how the present shortages have been allocated among consumers. As to the macro impacts, Nordhaus again agreed with Cooper that there would be a short-term but potentially severe decline in real output if the authorities failed to accommodate the increased prices. He found it likely that this loss would be considerably above any allocational gains from decontrol.

Hendrik Houthakker argued that U.S. experience with oil decontrol should lead us to be more sanguine than Cooper about prospects under gas decontrol. Contrary to previous predictions, the price of gasoline fell rather than rose after decontrol in 1981. Citing a study by the National Commission on Supplies and Shortages, Houthakker claimed that the main cause of the gasoline lines in 1973 and 1974 was the price control program then in effect. Taking into account the undesirable side effects of the present gas controls and those likely under decontrol, he preferred immediate decontrol if it were combined with a windfall profits tax. George Perry observed that most product prices had been decontrolled before 1981 and the main surprise was not about the effect of decontrol on gasoline prices but about the effect of world recession on world prices for crude oil.

Sims pointed out a more subtle problem with controlled prices in this context. Since gas is an exhaustible resource, the price plays two roles. 
In addition to allocating among current users, the rate of growth of prices affects the rate of exhaustion of resources. This implies that both the level and rate of growth of prices must respond in a particular way to remain efficient in changing market situations. Any benefit of gas price regulation should therefore be weighted against the likelihood of substantial errors by regulators in solving the complicated problem they face.

Barry Bosworth suggested that the macroeconomic impacts of deregulation were probably exaggerated in Cooper's paper. The first reason is that the DOE Study, on which some of the analysis rests, is no longer relevant because the market for energy is no longer tight. The second reason is that the controls have never been as effective as they were originally intended to be and as they are popularly thought to be. Private agents in the natural gas market are far more ingenious in avoiding the strictures of the NGPA than regulators are in enforcing them. Bosworth objected to the present controls mainly because they would prevent the authorities from rationally responding to energy-supply disruptions. The NGPA simply prevents reallocation of gas from surplus areas to shortage areas, and hence exacerbates the energy problems the nation would face in the event of an interruption in supply. 